\title{
The History of the Swedish ATM: Sparfrämjandet and Metior
}

\author{
Björn Thodenius ${ }^{1}$, Bernardo Bátiz-Lazo ${ }^{2}$, and Tobias Karlsson ${ }^{3}$ \\ ${ }^{1}$ Dept. of Management and Organization, Stockholm School of Economics, Sweden \\ bjorn.thodenius@hhs.se \\ ${ }^{2}$ University of Leicester and Bangor University, UK \\ b.batiz-lazo@le.ac.uk \\ ${ }^{3}$ Department of Economic History, Lund University, Sweden \\ tobias.karlsson@ekh.lu.se
}

\begin{abstract}
In this paper, we describe the first decades of the history of the Swedish Automated Teller Machine (ATM). Sweden was one of the pioneers in using ATMs, starting with cash dispensers or cash machines in 1967. The first machine was made operational and shown to the press on 6 July 1967 in Uppsala at Upsala Sparbank, only one week after the first cash machine in the world was made operational in the UK. The Malmö-based company Metior manufactured the Swedish machine. This paper seeks to document the origins and the early development of cash machines by Swedish savings banks, employing oral as well as archival sources. Interestingly, we find that the key actor behind the ATM technology was not Spadab, the computer company of the saving banks, but Sparfrämjandet, a company most well known for its campaigns to encourage thrift among children.
\end{abstract}

Keywords: Automated teller machines (ATM), cash dispensers, savings banks, Sweden, technological change

\section{Introduction}

Automated teller machines (ATMs) have been around for some forty years and today we can use the same card to withdraw cash all over the world. In this paper we describe the first decades of the history of the Swedish ATM. Sweden was one of the pioneers in using ATMs, starting with cash dispensers or cash machines in 1967 [1]. The first machine was made operational and shown to the press on 6 July 1967 in Uppsala at Upsala Sparbank, only one week after the first cash machine in the world was made operational in the UK [2]. The Malmö based company Metior manufactured the Swedish machine. This paper seeks to document the origins and the early development of cash machines in Sweden, employing oral as well as archival sources. Interestingly, we find that the key actor behind the ATM technology was not Spadab the computer company of the saving banks, but Sparfrämjandet, a company most well known for its campaigns to encourage thrift among children. This finding 
is, however, not as surprising as it may seem, since Sparfrämjandet also had the task to rationalize administrative functions among the savings banks. The ATM technology was not a coincidental innovation made by technicians. Rather, we should view it as part of a modernization process within the savings banks movement that took place in the light of intensified competition and rising transaction costs.

The reminder of this paper proceeds as follows. The next section provides some background regarding the origins and the growth of savings banks in Sweden. The third section documents the adoption of cash machines by Swedish savings banks and the way this development intertwined with the history of the engineering firm Metior (later to be Asea-Metior). The fourth and final section encompasses our conclusions.

\section{The Swedish Savings Banks - a Brief Overview}

During the first half of the twentieth century, competition between savings banks and commercial banks in Sweden was rather weak. Each bank had different customers and offered different services. In some instances they even came together to collaborate in joint projects. Whereas the commercial banks had experienced serious problems during the inter-war period, savings banks flourished while operating mainly in local and regional markets. Although their number had already started a downtrend (approaching 450 in 1945 and as few as 60 in 2008), their joint share of total deposits increased from 26 to 43 percent between 1920 and 1950 and profits were high [3].

The decades that followed the end of World War II were characterized by overall economic growth, increased affluence and expansion of the welfare state in Sweden. This era also saw increased competition in the banking sector as the commercial banks began to widen their customer base (while aiming to attract all sorts of new customers, from companies to wage earners). Handelsbanken, for example, launched itself as the "people's bank" in 1950. Shortly afterwards, Handelsbanken and other commercial banks used the contacts developed while financing the working capital of manufacturing companies to offer these companies direct payroll deposit services.

The savings banks were initially hesitating to this new service. However, a group of younger managers pushed for a more aggressive corporate strategy [1, 3]. Throughout the 1950s, these young managers were under the leadership of Sven G. Svensson, director of Sparfrämjandet, who also organized annual conferences in Saltsjöbaden to facilitate the meeting of like-minded young managers [3]. They united with the idea that the savings banks had to adjust to ongoing social change. Furthermore, their conviction was that the savings banks should meet the challenge of Handelsbanken and other commercial banks, not by demanding protection from the state but by introducing better services. Many ideas that emerged from the conferences at Saltsjöbaden were implemented during the 1960 s as the attendants reached influential positions within the savings banks. As a result, the Swedish savings banks evolved from small-scale savings institutions to "modern" businessoriented banks. During this process, the emphasis on thrift was downplayed while the savings banks began to view depositors more like customers than savers.

Rocketing administrative costs provided a strong incentive for the savings banks to seek greater labor efficiency through the application of new technologies. As 
suggested by Table 1 , the increase in the nominal value of deposits accompanied an increase in the value of administrative costs (measured as a percent of total deposits). It is with this background that they intensified efforts to introduce mainframe computers for various tasks during the 1960s.

Table 1. Administration costs in the 80 biggest Swedish savings banks, 1962-67 [1].

\begin{tabular}{lll}
\hline Year & Million SEK & \% of deposits \\
\hline 1962 & 114 & 0.847 \\
1963 & 128 & 0.895 \\
1964 & 150 & 0.963 \\
1965 & 176 & 1.063 \\
1966 & 213 & 1.124 \\
1967 & 257 & 1.194 \\
\hline
\end{tabular}

As mentioned, the savings banks were late to respond to the direct payment of payroll service offered by commercial banks. This attitude was to change in 1960 when most of the bigger savings bank introduced that service. However, unfortunately, the number of individual accounts they managed to attract proved to be much lower than expected. This became evident two years later in 1962 when the commercial banks had more than twice as many accounts as the savings banks $(387,000$ and 143,000 , respectively). However, close links with trade unions helped the savings banks to transform their position and eventually dominate the direct payroll payment service. By the end of 1970, the savings banks had no less than 870,000 accounts $[1,3]$. Table 2 below illustrates the way growth in business volume accompanied an increase in staff in Sweden.

Table 2. Estimated number of employees and deposits in Swedish savings banks, 1962-67 [1].

\begin{tabular}{lllll}
\hline Year & $\begin{array}{l}\text { Number of } \\
\text { employees }\end{array}$ & $\begin{array}{l}\text { Increase } \\
\text { in \% }\end{array}$ & $\begin{array}{l}\text { Deposits } \\
\text { million SEK }\end{array}$ & Increase in \% \\
\hline 1962 & 3,500 & & 17,699 & \\
1963 & 4,100 & 17 & 18,957 & 7 \\
1964 & 4,700 & 15 & 20,531 & 8 \\
1965 & 5,200 & 11 & 22,263 & 8 \\
1966 & 5,800 & 12 & 24,511 & 10 \\
1967 & 6,400 & 10 & 27,259 & 11 \\
\hline
\end{tabular}

While increased involvement in direct deposit of payroll reduced the number of checks passing through the banking system, the savings banks found that this involvement was not without costs. To keep up with the commercial banks, the savings banks had to expand their workforce. This resulted in payroll and related costs growing faster than the pace at which the value of total deposits increased. Consequently, administration costs bolted. Administration costs (expressed as a share of deposits) increased by 40 percent between 1962 and 1967. Table 3 below 
summarizes a closer study of the four largest savings banks. It revealed that the number of transactions (withdrawals and deposits) increased by 125 percent, whereas their total funds increased by 64 percent [1].

Table 3. Transaction volume and deposits in the four biggest Swedish savings banks, 1962-67 [1]

\begin{tabular}{lll}
\hline Year & $\begin{array}{l}\text { Number of deposits and } \\
\text { withdrawals }\end{array}$ & $\begin{array}{l}\text { Value of deposits in } \\
\text { million SEK }\end{array}$ \\
\hline 1962 & $2,011,600$ & 989 \\
1963 & $3,077,600$ & 1,062 \\
1964 & $3,528,900$ & 1,147 \\
1965 & $3,843,300$ & 1,246 \\
1966 & $4,473,000$ & 1,425 \\
1967 & $4,526,700$ & 1,626 \\
\hline
\end{tabular}

Another aspect of the modernization of the Swedish savings banks that took place in the 1960s was concentration. In the beginning of the 1960 s, there were still over 400 individual savings banks in Sweden. Because of amalgamation between small units operating in the countryside and city-based entities, only 273 savings banks remained in 1970. The concentration process went on during the following decades with merges between the biggest banks. By 1989, there were 109 savings banks left, but this population consisted of 20 big banks with regional coverage holding 80 percent of total deposits, and 95 local banks [3].

Rising administrative costs and an increasing number of accounts in the late 1950s and the 1960s required Swedish savings banks to take urgent action. A major step towards computerization occurred in 1958 when a Technical Committee formed within the Swedish savings banks association. Per Olov Rimvall, a committee member was a driving force behind research to solve the "bookkeeping problem" in the savings banks. Eventually he initiated the formation of a commonly owned computer and data processing company in 1961, later called Spadab. However, to all appearances, Spadab did not play a central role in the development of cash machines. Within the saving banks movement, the agent of change occurred in another organization, namely Sparfrämjandet.

\section{Sparfrämjandet and Metior}

\subsection{Sparfrämjandet}

Originally, Sparfrämjandet was the propaganda department of the Swedish savings banks association. According to Hessling [4], this department had three main aims. First, the department encouraged thrift, both internally within the savings banks and 
externally among the public. Second, it served as a publishing house. Third, the department became a central purchasing unit to coordinate purchases of material that the savings banks needed in their retail branches. The department regularly published printed material and was responsible for launching national campaigns. In 1941, the propaganda department was renamed Sparfrämjandet and in 1943, it became an independent company. One reason to change the name was the negative connotation of the term "propaganda." The new Sparfrämjandet had three departments, namely publishing, external relations, and central purchasing.

Sparfrämjandet was the initial driving force for savings banks to adopt cash dispensers because the central purchasing department of Sparfrämjandet had a parallel development within automation. In 1960, Hans Rausing and the Rausing company started to develop and sell coin sorting machines to the savings banks. This later became the firm Restello, a company within the Tetra Pak group.

For some years, the saving banks and Sparfrämjandet had been discussing the possibilities of automating cash dispensing to rationalize the bank tellers' handling of cash in the bank offices. One other need was to make it possible to distribute cash when the bank offices were closed, especially as had been the case in Britain, after the banks closed retail branches on Saturdays in 1969.

\subsection{The Metior Cash Dispenser}

Sparfrämjandet wanted some type of machine or automat that was able to dispense bank notes and discussed the issue with Metior, a company in the Tetra-Pak group that manufactured automatic petrol pumps and had taken over production of the Restello coin sorting machines. The discussions went on for some time but the cooperation was not fully successful. Metior then contacted the commercial bank Svenska Handelsbanken who became the new partner in the development of a cash dispenser [1, 5]. According to Körberg [1], Bengt Wetterholm, the CEO of Spadab at that time, reinitiated the contacts with Metior when learning about the interest of Svenska Handelsbanken $[1,6]$.

Here it is worth noting that there are very few references to Spadab in Metior's archives. It seems like the company mainly had contacts with Sparfrämjandet and that this organization influenced the design of the first generations of cash dispensers in Sweden. For example, when Metior was about to demonstrate its first machine in December 1966, it invited a representative from Sparfrämjandet but no one from Spadab.

The initial demonstration was planned for 11 January 1967 in Malmö. There were also plans to start testing the machines in Uppsala in January or February that same year. It is unclear whether the demonstration and subsequent tests actually took place according to plans, but we can establish that the first Swedish cash machine became operational and shown to the press on 6 July 1967 in Uppsala. This was only nine days after the first British cash machine was operational by Barclays Bank and De La Rue, and a couple of days before Svenska Handelsbanken showed its first Metior machine.

After some months of testing, the public started to use the cash dispenser in Uppsala twenty-four hours a day in September of 1967. The first machine had some 
problems and it took some time to get them sorted and make the machine operational most of the time.

In early 1968, Metior had manufactured five machines. Metior still called them prototypes and of these five machines, the savings banks had two and the commercial banks three. In the spring of 1968, mass production began because Sparfrämjandet ordering twenty machines. This order included a number of specific requirements, indicating that the savings banks actively contributed to shape the new technology.

They delivered about twenty machines to Switzerland and one to the Netherlands. Each machine sold at 58,000 to 59,000 SEK. About a year later, in April 1969, the Swedish savings banks ordered Metior cash dispensers for 1.8 million SEK, Metior's biggest order so far. By February 1970, Metior had delivered 37 cash dispensers for the Swedish market, of which savings banks bought 24. At the same time, Metior had exported 141 cash dispensers. For instance, Metior had achieved a dominating position in Switzerland, where De La Rue had left the market, and was about to enter the French market in collaboration with Transac, a division of Compagnie Industrielle des Télécommunications (CIT).

The first cash dispenser went under the name "utbetalningsautomat" and later "Bankomat." However, Svenska Handelsbanken and the commercial banks soon acquired this name as the brand name for their dispensers. During its initial years, Metior developed four generations of cash dispensers. The first generation was not sold commercially. They developed the second and third generations for savings banks and the fourth for commercial banks and the French market.

Bankomat Mark 2 and 3 were made of steel and had punched holes for identification, while in the UK Chubb's plastic card had punched holes, Barclay-De La Rue used a cheque-sized voucher with a magnetic stripe and Speytec-Burroughs' plastic card had a magnetic stripe on the back [7]. Bankomat Mark 4 used a card with information embedded in a magnetic stripe that had been developed by the French Société Générale de Automation. To withdraw money from the Metior machines, a one used a PIN-code together with the card.

Whereas UK banks had been adamant not to deploy machines until their security had been tested [7], some years after the first Swedish machines were being used the security of the system became an issue. Withdrawals using fake cards started to appear. Someone had discovered the algorithm used to associate card numbers with the PIN-code. One Easter holiday someone travelled around Sweden, withdrawing money from each machine visited. This led Metior to contact Bofors in order to help with the security issues. The cooperation led to Bofors buying 80 percent of Metior's shares on 31 August 31 1969. However, Bofors' interest and competence on these security issues regarding cash dispenser were insufficient. New problems emerged in October of 1971 and of such magnitude that the savings banks considered closing down its whole fleet of Metior machines. As a result, Bofors sold the control of Metior to ASEA in 1973.

It is interesting to note that the Easter holiday incident lead to a change in the internal regulations of the savings banks. Before the incident, the retail branch that had the dispensers was solely responsible for losses that might arise. This changed after the incident so that all savings banks collectively shared any losses resulting from the malfunction of cash machines. 
Already at an early stage, in May 1968, Metior delivered the first machine connected online to the Malmö computer center. The second to fourth generations of Bankomats were all able to connect online via modem and Mark 4 connected to a call system. However, most cash machines at the savings banks operated as stand-alone, off-line machines.

A turning point came in 1971 because of two developments. First, commercial banks within the Swedish Bankers Association, the post office, and the Federation of Swedish Rural Credit Societies set up the Automatic Cash Dispenser Center. The aim of this independent company was to install and run cash dispensing equipment for the consortia, determine where the machines would be located, market its services (under the Bankomat brand) and administer card registration, data processing, clearing and statistical information. In November 1972, fifteen Asea-Metior cash machines became operational for the consortia in Stockholm. In 1973, thirteen machines became operational in Gothenburg and one more in Stockholm. The following year, ten more dispensers became operational in Stockholm. By 1974, the savings banks remained outside of the consortia that, at the same time, aimed to deploy one hundred machines throughout Sweden to service 1.8 million direct payroll deposit accounts. Between November 1972 and January 1974, banks in the Automatic Cash Dispenser Center consortia issued 29,443 cash machine cards and dispensed some SEK 66 million (USD 14.54 million), with an average withdrawal equal to SEK 268 (USD 59).

A second important development took place when the new director of Spadab, Jan Rydh, attended the Automated Teller Machine Conference in Chicago in 1971. Rydh reminisced that during discussions dwelling on investments in off-line dispensers on the fringes of the conference, out of impulse he made the sudden decision to regard investments in off-line machines a sunk (i.e. irrecoverable) cost [8]. Colleagues attending the conference received the decision; upon their return to Sweden, engineers at Spadab were free to start what became the Minuten project. The aim of this project was the adoption of online cash dispensers by the savings banks. In search of potential suppliers, they made contacts with a number of manufacturers of cash dispensers and in the end, three companies competed for the project. These were the Swedish company Asea-Metior, the British company Chubb, and the US-based Docutel. Resulting deliberations caused savings banks to abandon Metior in 1975 by choosing Docutel as their supplier of ATM devices (online cash machines).

There are several competing explanations behind the move by the savings banks to abandon Metior. One major factor, however, was the weak US dollar at that time which made the Asea-Metior dispenser more costly than the Docutel machine [8]. Datasaab handled the installation and service in Sweden. This engineering company was at the start of its collaboration with Leif Lundblad and his Stockholm-based Inter Innovation company. Lundblad had developed its own cash dispensing mechanism to accommodate the differences between dollar notes and European currencies. The experience which Datasaab had acquired of the Docutel machines combined with Lundblad's dispensing mechanism, led to the decision to develop a Datasaab ATM. However, before presenting a working machine, Datasaab became part of Ericsson Information Systems. It produced and installed a few machines in a number of countries.

The savings banks were the first to use this new generation of ATMs. These ATMs were initially known as mini-banks and 'Minuten' and the first machine was installed 
on 24 May 1977 in the city of Falun. In total, Docutel installed 600 machines [5]. From the beginning, all Minuten machines were connected online. In 1982, Spadab searched the market for a new generation of ATMs. Spadab wanted to buy 1,000 new ATMs. The machine that Datasaab had started to develop did not fulfill the demands of Spadab. Instead, Ericsson contacted Omron; in 1984, they signed a contract and started deploying new ATMs. In total, they delivered to the savings banks 900 ATMs of this type.

The Minuten network competed with the network built around the commercial banks (called "Bankomat"). In later years, clearing agreements between the two networks allowed bank customers to use each other's network.

\section{Conclusion}

In this paper, we have explored the first steps in the emergence of self-service technology in banking. The focus has been on the savings banks, since they played an especially important part in the early development. It would also be interesting to investigate closer the early development in Svenska Handelsbanken before 1966-67.

Our purpose has been to research technology and corporate strategy in their social and historical context, that is, the dynamics of the design, construction, development, implementation and use of specialized technology $[9,10]$

What we find among the most interesting aspects in the early development is the key role of Sparfrämjandet and that the interest of the saving banks' computer company Spadab seems to have been low in the beginning. This finding is, however, and as stated before, not as surprising as it may seem, since Sparfrämjandet also had the task to rationalize administrative functions among the savings banks.

We also note that the ATM technology was not a coincidental innovation made by technicians. Rather, we should see it as a part of a modernization process in the savings banks movement that took place in the light of intensified competition and rising transaction costs.

The role of the company Metior is also crucial for the early development and it would be interesting to make deeper studies of the company and its roots. The exact story of the first online machines also requires further investigation.

\section{References}

1. Körberg, I.: Förnyelsen: Sparbankernas historia 1945-1980. Ekerlids förlag, Stockholm (2006)

2. Bátiz-Lazo, B.: Emergence and Evolution of ATM Networks in the UK, 1967-2000. Business History 51(1): 1-27 (2009)

3. Forsell, A.: Moderna tider i Sparbanken: Om organisatorisk omvandling i ett institutionellt perspektiv. Nerenius \& Santérus förlag, Stockholm (2002)

4. Hessling, T.: Att spara eller inte spara - vilken fråga! Den sparfrämjande verksamheten 1920-1970. Sparfrämjandet, Stockholm (1990)

5. Wentzel, V.: Pengar på Minuten. In: Hallberg, T.J. (ed.) Tema bank: Datasaab och bankerna (1996) 
6. Elanders $\mathrm{AB}$, Västerås, The Archive of Metior $\mathrm{AB}$ (MAB), Huvud- och dagböcker (HD) 1966-1971, (Series 1), Volumes 8-14

7. Bátiz-Lazo, B., Reid, R.: Evidence from the Patent Record on the Development of Cash Dispensers and ATM Technology. IEEE History of Telecommunications Conference, Paris (2008)

8. Thodenius, B.: Teknisk utveckling i bankerna fram till 1985: Transkript av ett vittnesseminarium vid Tekniska museet. Trita-HST 2008:26. KTH, Philosophy and History of Technology, Stockholm (2008)

9. Orlikowski, W., Barley, S.: Technology and Institutions: What can Research on Information Technology and Research on Organizations Learn from Each Other? MIS Quarterly 25: 145-65 (2001)

10. Bridgman, T., Willmott, H.: Institutions and Technology: Frameworks for Understanding Organizational Change - the Case of a Major ICT Outsourcing Contract. Journal of Applied Behavioural Science 42(1): 110-26 (2006)

\section{Appendix: Secondary Sources}

Bátiz-Lazo, B., Del Angel, G.: Competitive Collaboration and Market Contestability: Cases in Mexican and UK banking (1945-75), Accounting, Business and Financial History 13(3): 1-30 (2003).

Bátiz-Lazo, B., Maixé-Altés, J. C.: Managing Technological Change by Committee: The Computerization of Savings Banks in Spain and the UK (circa 1960-1988). BHC/EBHA Joint Conference. Milan (2009)

Bátiz-Lazo, B., Maixé-Altés, J. C.: Organisational Change and the Computerisation of British and Spanish Savings Banks, circa 1950-1985. XVth World Economic History Congress Utrecht (2009)

Bátiz-Lazo, B., Wardley, P.: Banking on Change: Information Systems and Technologies in UK High Street Banking, 1919-1969. Financial History Review 14(2): 177-205 (2007)

Bridgman, T., Willmott, H.: Institutions and Technology: Frameworks for Understanding Organizational Change - the Case of a Major ICT Outsourcing Contract. Journal of Applied Behavioural Science 42(1): 110-26 (2006)

Ekebrink, I.: Cash Dispensing: A Joint Venture in Sweden, Magazine of Bank Administration: $10-12$ and 63 (1974)

Elanders AB, Västerås: Metior AB (MAB), Huvud- och dagböcker (HD) 1966-1971, (Series 1), volumes 8-14

Frame, W. S., White, L. J.: Technological Change, Financial Innovation, and Diffusion in Banking. Atlanta, GA, Federal Reserve Bank of Atlanta (2009)

Guerriero Wilson, R.: 'The Machine Should Fit the Work': Organisation and Method and British Approaches to New Technology in Business. History and Technology 24(4): 321-333 (2008)

Spadab: Från fjäderpenna till microchip: Den tekniska utvecklingen i sparbankerna. Stockholm, Sparfrämjandet (1987)

Swedbank Central Archive, Stockholm: Spadab files, several. Anonymous, 'Diverse', May 6, 1965 